\title{
THE NEW YUGOSLAV CRIMINAL CODE
}

\author{
RICHARD G. DOHMELLY*
}

THE new Yugoslav Criminal Code, ${ }^{1}$ which became effective on July 1, 1951, is of twofold interest to students of criminal law. First of all, it is a contemporary specimen of codification. More importantly, it is an instrument reflecting the ideological assumptions of a Communist State.

The achievement of justice in criminal cases depends upon four interacting variables: personnel, administration, procedure, and the substantive law of crimes. Criminal law reformers have been concerned chiefly with the first three. For example, there have been important studies of crime catsation and legal responsibility. The revulsion against retribution as the aim of punishment-generated by Nineteenth Century Humanitarianism-has been fortified by the new insights into human motivation revealed by the behavior sciences. The development of probation, parole, and other release procedures as alternatives to penal commitment, and the individualization of sentencing and treatment, are other trends of significance. The American Law Instittte's Code of Criminal Procedure and the recent Federal Rules of Criminal Procedure have given impetus to needed improvements in criminal procedure. In the end, however, criminal justice must rest upon a satisfactory substantive law of crimes. Although Great Britain and the United States stand in the vanguard of the penological reform movement, the forces directing this movement have shown little interest in the criminal law proper. In fact, the substantive law of crimes in the United States remains uncertain, obscure, formally defective, inconsistent and antiquated. ${ }^{2}$ If by codification is meant the effort to simplify, synthesize and systematize law by the positive legislative formulation of inclusive and operationally defined principles, Great Britain and the United States have lagged far behind Continental countries. There are compilations of statutes, sometimes designated as codes and sometimes not, but these are rarely systematic bodies of law. There have been sporadic and haphazard amendments to the statutes but these have been

*Associate Professor of Law, Yale Law School.

1. An English translation of the Code appears in 2 New YucosLAv L., No. 2-3, pp. 39-115 (1951). This periodical is published by the Federation of Jurists' Associations of Yugoslavia.

The same issue contains a speech by Minister of Justice Frane Frol before the joint session of Legislative Committees of the National Assembly, which considered the Draft Code. I have relied heavily upon this speech as an official statement of the policics behind and the objectives of the Code.

2. Mikell, The Criminal Code of Penisylvania, 65 U. of PA. L. REv. 232 (1917); Wechsler \& Michael, A Rationale of the Law of Homicide, 37 Col. L. REv. 701 (1937); Pound, Criminal Justice in America 142-8 (1930); Mannhein, Crininal Justice aNd Soctal Reconstruction (1946). 
mostly patch-work jobs. Except for the 1942 Louisiana Code, ${ }^{3}$ there have been but few major efforts to codify the substantive law of crimes. 1

On the Continent a considerable number of new codes have been adopted. These reflect ideas of criminology and criminal policy which have developed since the era of the Napoleonic Code. The twenties and thirties vitnessed the Soviet penal codes of 1922 and 1926, the Yugoslav Criminal Code of $1929{ }^{5}$ the draft of the German Penal Code of 1930, the Italian Penal Code of 1930, the preliminary draft of the general part of the French Code of 1932, the Polish Penal Code of 1932, and the Swiss Federal Criminal Code of 1937. In 1950, Czechoslovakia enacted a new Criminal Code ${ }^{b}$ and in 1951, the new Greek Code and Yugoslav Code became effective.

Codification in the United States will be more meaningful in terms of content as well as formal statement if the codes of other systems are studied. The systematic study and knowledge of what is going on in other countries is indispensable if we would make our system of criminal law the best possible instrument of justice. Furthermore, a modern codification prepared on the basis of comparative studies should encourage American legal scholars to participate more effectively than in the past in ventures in international collaboration. . A second reason for interest in the new Yugoslav Code is that "the criminal law has, quite rightly, been called one of the most faithful mirrors of a given civilization, reflecting the fundamental values on which the latter rests." The formulation of a criminal code not only entails value judgments as to the sort of social order desired. It also includes a policy decision regarding the extent to which the criminal law is an effective and desirable instrument for protecting and fostering the values and institutions which are favored in a given society.

The draftsmen of the Yugoslav Criminal Code obviously were influenced by Soviet legal theory. This theory, following the lines of classical Marxian thought, originally looked upon the State and Law as superstructures erected

3. La. Act 43 of 1942. And see, Smith, How Lousiana Prepared asd Adoptcd a Criminal Code, 41 J. Crisr. L. \& Crnmology 125 (1950).

4. For a general review of codification see Dessron, Crunmur Law, Adusnisstration and Publtc Order 393-6 (1948) and David Dudley Find Centemany Essays (Reppy ed. 1949).

In 1935 the American Law Institute approved the preparation of a model criminal code. The project, which has lain dormant, has recently been revived.

5. For a discussion of this earlier Yugoslav Code as well as the Codes of Poland and Czechoslovakia, consult Gsorski, New Codes IN THE SLAuc Countares (1934).

6. A French translation of the New Czech Code appears in 8 Bulletr: DE. Drolt TCHécoslovague 457 (1950). A supplement to volume 30 of the Journal of Criminal Law and Criminology contains an English translation of the Swiss Federal Criminal Code of 1937.

6a. Current deliberations under the auspices of the United Nations on the project for an international criminal code is a case in point. For a series of articles on the subject see 46 Axr. J. InT'L L. 1 et seq. (1952).

7. Mannnerns, Crominal Justice and Social Reconstruction 2 (1946). 
upon the foundations of bourgeois society. They were to be utilized by a proletarian dictatorship only for the relatively short transitional period preceding the achievement of collectivism. As long as law was regarded as a "bourgeois fetish" bound to "wither away" a specific theory of Socialist law was impossible. With the realization of socialism in the thirties, Soviet theory began to resurrect the State as a mechanism essential to the organization of a Socialist society which would endure for an indefinite period. This shift in outlook decisively changed the perspective of Soviet legal theory. Instead of withering away, law was restored on a large scale not only as a necessary base for a stable society but as a positive tool for securing and developing the Socialist order. ${ }^{8}$ A similar view was taken by the Yugoslav draftsmen. They consider the Criminal Code an instrument for the development of socialism. This is clear from the concept of crime which it entunciates.

\section{CONCEPT OF CRIME}

The objective of the Code is stated in Article 1 to be the protection "from violence, arbitrary treatment, economic exploitation and other socially dangerous acts, [of] the person of citizens, their rights and freedoms guaranteed by the Constitution and laws; [of] the political, national, economic and social foundations of the Federative People's Republic of Yugoslavia, its independence and security, its socialist social order and state organization established by the Constitution and law." This protection is to be achieved by "determining which socially dangerous acts shall be considered as criminal offences, by prescribing punishments, measures of security and educationalreformatory measures, and by application of such punishments and measures towards perpetrators of criminal offences through a procedure determined by law." Article 4 then defines a criminal offense as "a socially dangerous act, the elements of which are defined by law."

This notion of crime as a "socially dangerous act" is not new. It is found in the writings of the Italian Positivists, ${ }^{9}$ and the Soviet law makers were the first to put the idea into positive law. ${ }^{10}$ The principle of social danger

8. This change in Soviet legal theory is discussed in Berman, Principles of Soviat Criminal Law, 56 YAle L. J. 803 (1947); Starosolsky, Basic Principles of Sovict Criminal Lawe, 28 N.C.L. Rev. 359 (1950); Fuller, Pashukanis and Vyshinsky: A Stmly in the Development of Marixian Legal Theory, 47 MICrr. L. Rev. 1157 (1949). Moro elaborate studies are Schlesinger, Soviet Legal Thigory (1945); Soviet Legal PurLOSOPHY (translated by Babb and including' excerpts from the writings of Lenin, Pashu* kanis, Vyshinsky, Trainin and others. 1951); and BERMAN, Justice in Russis (1950).

9. See, e.g., Ferri, Criminal Sociologx 318-64, 454 (1917). In 1921, Ferri presented a draft of an Italian Criminal Code based upon the idea of social danger rather than guilt and upon measures of social defense rather than punishment. This draft, which was not accepted, is discussed in Cantor, Crime and Society 214-19 (1939).

10. The Criminal Code of the Russian Republic provides:

"Art. 1. The penal legislation of the R.S.F.S.R. has the task of protecting the socialist state of workers and peasants and the established order therein against 
initially discarded guilt as the touchstone of criminal responsibility. "Measures of social defense" were substituted for punishment.11 Recently the Vishinsky era occasioned a retreat from the original position. Both "guilt" and "punishment" are now discussed in the commentaries, textbools, and articles. The present theory is that "social danger" is but the objective and material characteristic of a crime. Guilt is the subjective element. 12

For the Yugoslavs as well, a criminal offense is more than a formal breach of law. The behavior must also constitute a danger to the social order which the criminal law was designed to protect and foster. Even though an act includes all the elements of a particular offense, Article + provides that it shall not be considered a criminal offense if it represents "insignificant social danger because of its slight importance and because of the insignificance or absence of detrimental consequences." 13

\section{The Principle of Legality}

In a time characterized by rapid political, economic and social change, the criminal law can fulfill its functions only if some technique can be devised to make it more readily adaptable than it has been. Some of the possibilities are: (1) the use of general terms; (2) the use of analogy in the interpretation of criminal statutes; or (3) periodic revision. The first two alternatives collide with the principle of legality. ${ }^{14}$ On the Continent this principle has

socially-dangerous acts by applying to persons committing them the measures of social defense set forth in the present Code.

Art. 6. Every act or omission is considered sucially dangerous which is directed against the Soviet regime, or which violates the order of things established by the workers' and peasants' authority for the period of transition to a Communist regime."

With respect to social danger, Professor Mannheim has observed that the function of the criminal law is no longer primarily to protect individual rights and interests, but at least as much to protect the rights and interests of the community at large. MIAxi:heims, Crminal. Justice and Soctal Reconstruction 195 (1946).

11. Pashukanis, The General Theory of Law and Miarisisas in Somet Legnt Phinosophy 111, 207-25 (1951).

12. Berman, Principles of Sovict Criminal Law, 56 YALE L.J. S03, 805 (1947); Trainin, Fundamental Principles of Soviet Criminal Law, 95 L. J. 259 (1945); Starosolsky, Basic Principles of Soviet Criminal Law, 28 N.C.L. REv. 359, 366 (1950).

13. The Soviet Codes contain a similar provision. For example:

"If a particular act is a crime within the meaning of Article 6 above at the moment when it is committed, but by the time it comes up for investigation or trial it has lost its socially dangerous character by reason of a change in the penal law or by virtue of the fact of the alteration of the social-political situation, or if the person who performed the act cannot now in the opinion of the court be considered socially dangerous, the act shall not render the person who performed it liable to the application of a measure of social defense." Cansmisl Cons, R. S. F.S.R, ART. 8.

14. For a thoughtful study of the principle of legality, consult HAL, GeriernL Principles of Crinunal Law 19 (1947). 
been formulated with definite reference to the criminal law in the phrase nulla poena, mullum crimen sine lege. Its implications are that no act shall be punished unless it was previously made punishable by law (nullum crimen), and that the actual penalty for a punishable act must likewise be legally predetermined (nulla poena sine lege). In American law the principle has found expression in the rule that penal statutes are to be construed strictly against the state and in favor of the accused, ${ }^{15}$ in ex post facto and bill of attainder provisions, ${ }^{16}$ in the constitutional prohibition on vaguely drawn statutes, ${ }^{17}$ and in the ejusdem generis limitation on catch-all statutory provisions. ${ }^{18}$

On June 28, 1935, the German government adopted a statute which was regarded in many quarters as a flagrant manifestation of the legal philosophy of National Socialism. It provided:

"He shall be punished who commits an action which the law declares to be punishable or which is deserving of punishment according to fundamental ideas of a penal law and the sound perception of the people. If no determinate penal law is directly applicable to the action,

15. Professor Livingston Hall has demonstrated that the strict view on the conlstruction of criminal statutes is wavering. Hall, Strict or Libcral Construction of Penal Statutes, 48 Harv. L. REv. 748 (1935).

16. U.S. Const. ART. I, $\$ \S 9 \& 10$.

17. Winters v. New York, 333 U.S. 507 (1948); Lanzetta v. New Jersey, 306 U.S. 659 (1939).

The proper legislative technique for drafting criminal statutes presents a difficult problem. Soviet legislators have been criticized because of their predilection for gcheral and vague terms. On the other hand, the opposite extreme of using narrow and detailed definitions has had disappointing results and has probably encouraged evasions. The technically most accomplished Penal Codes, such as the Swiss Code of 1937, take a middle of the road approach with a slight bias towards the use of general terms and the elimination of avoidable detail. The Reporters who prepared the draft of the Louisiana Code followed a similar path. "It has been the consistent policy of the Reporters to draft the individual articles as concisely as possible. To avoid resorting to lengthy cnumerations, broad terms have been used whenever practicable, but only after carciul consideration of pertinent decisions and commentaries to guard against the selection of terms that might be too inclusive." Louisiana State Law Institute, Project bF $A$ Criminal Code for the State of Louisiana viii (1942).

Although the use of wide and ambiguous terms is incompatible with the principle of legality and offends constitutional prohibitions on vagueness, American lawyers should not be too self-righteous about this. For example, the conception of conspiracy in AngloAmerican law is "elastic, sprawling and pervasive." Justice Jackson, concurring, in Krulewitch v. United States, 336 U.S. 440, 445 (1949). Other pneumatic concepts are "public mischief" [King v. Manley [1933] 1 K. B. 592], "vagrancy" (Note, 59 YALE L. J. 1351 (1950), "obscene" (Judge Jerome Frank concurring in Roth v. Goldman, 172 F.2d 788, 794 (2d Cir. 1949), and "sacrilegious" (Joseph Burstyn, Inc. v. Wilson, 101 N.E. 2d 665) (N.Y. Ct. Appeals 1951).

18. See Cleveland v. United States, 329 U.S. 14 (1946); United States v. Alpers, 338 U.S. 680 (1950). 
it shall be punishable according to the law, the basic idea of which fits it best."19

Next to the National Socialist Act, Article 16 of the Soviet Penal Codes has become the most widely known provision in favor of punishment by analogy. This article declares:

"Where a socially dangerous act has not been expressly dealt with in the present code, the basis and limits of responsibility in respect thereof shall be determined in conformity with those articles of the code which deal with the crimes most closely resembling it."

Once crime is defined as a socially dangerous act, punishment by analogy is logically unavoidable. Behavior not specifically condemned but similar to that which is may be socially dangerous. Analogy is merely the converse of the proposition that there is no criminal responsibility for an act which meets the particular elements of a crime but lacks social danger..$^{20}$

Punishment by analogy is not a sine qua non for a tyrannical state. Italy, for example, forbade analogy. Yet, by the use of widely drawn statutes and extra-legal techniques, the Fascists achieved a police state. ${ }^{21}$ On the other hand, a democratic country like Denmark permits it."2 Analogy is, however, symptomatic of governments that place the protection of the State from the risk of disorder far above the protection of the individual from the risk of oppression..$^{23}$ Nevertheless, it is naive to assume that the mere prohibition of analogy will safeguard civil liberty.

19. This statute is discussed in Note, The Use of Analogy in Criminal Law, $47 \mathrm{Coz}$ L. Rev. 613, 615 (1947) and MLanneerar, Criminal Justice and Soctar. ReconsmucIION 208 (1946).

20. The use of analogy in Soviet law is examined in Berman, Principles of Sorict Criminal Law, 56 YaLe L. J. 803, 809 (1947); Starosolsky, Basic Principles of Scrict Criminal Law, 28 N.C.L. Rev. 359, 369 (1950). Also consult Hazard \& Weisnerc, CASes and Readings on Sovtet law 50 (mimeo. 1950).

21. Weidenbaum, Liberal Thought and Undefined Crimes, 19 J. Cour. LEG. \& InT't. L. (3d ser.) 90, 96 (1937).

22. Minarafeetas, Criminai Justice and Soctal Reconstruction 208 (1946).

23. Two months after the enactment of the German statute introducing analozy, the Senate of the Free City of Danzig adopted a similar provision. This vas reviewed by the Permanent Court of International Justice and found to be inconsistent with the fundamental rights guaranteed by the Constitution of Danzig.

"The problem of the repression of crime may be approached from two different standpoints, that of the individual and that of the community. From the former standpoint, the object is to protect the individual against the State: this object finds its expression in the maxim Nulla poena sine lege. From the second standpoint, the object is to protect the community against the criminal, the basic principle being the notion Nullum crimen sine poena. The decrees of August 20th, 1935, are based on the second of these conceptions; the Danzig Constitution is based upon the former. For this Constitution takes as its starting-point the fundamental rights of the individual; these rights may indeed be restricted, as already 
The Yugoslav Code abandons analogy. The return to the principle of legality was extolled by Minister Frol as follows:

"[T]he application of criminal-juridical sanctions cannot and must not be left to wilful and arbitrary practices but must be established by the law itself. This means that the realization of protection of our socialistic social and state order from criminal offences must be sought through law, that the principle of legality must be honoured to the fullest extent....

"Today we are in a position to abandon analogy in virtue of enacting a complete and unified Criminal Code.... In this manner the proposed draft binds even closer together the basic element of any criminal offence, the social danger, with the familiar principle of 'nullum crimen sine lege', which marks a new advance of our socialist legality in the sphere of criminal law."24

This eulogy must be taken with skepticism because Minister Frol, after praising the Special Part ${ }^{25}$ of the Code for its definiteness and concreteness of statement and its avoidance of vague and flexible terms, sounded this warning:

"All this signifies the consolidation of the principle of legality in the province of criminal law and a guarantee for the successful realisation of that principle. But even so, sheer facts are not, nor can they be, the concepts employed for the determination of elements of individual crimes under the draft as this would be reducing the role of

pointed, out, in the general public interest, but only in virtue of a law which must itself specify the conditions of such restriction, and, in particular, determine the limit beyond which an act can no longer be justified as an exercise of a fundamental liberty and becomes a punishable offence. It must be possible for the individual to know, beforehand, whether his acts are lawful or liable to punishment.".

Consistency of Certain Danzig Legislative Decrees with the Constitution of the Frec City, Permanent Court of International Justice, Advisory Opinion, December 4, 1935. Publications of the Court, Series A/B No. 65, at 41,56,57. This opinion is abstracted in Dession, Criminal Law, Administration and Public Order 142 (1948).

24. Frol, A Summary of the Draft Criminal Code, 2 New Yucoslav L. 4, 8 (1951). The pertinent articles of the Code are as follows:

"Article 2. No punishment may be imposed on anyone for acts which, prior to being committed, did not constitute criminal offences under the law and concerning which no punishment had been prescribed for the perpetrators thereof.

Article 26(1). Punishment of death, imprisonment, detention and confiscation of property may be imposed only when so prescribed by law for a specified criminal offence."

25. The Yugoslav Code follows the pattern of the more highly developed penal codes in that it is divided into a General and a Special Part. The General Part sets forth major principles of general applicability. It is followed by a Special Part containing sixteen chapters classifying and defining particular offenses and prescribing the applicable punishment. 
the Court to a purely mechanical-logical function of subsumption. The draft, on the contrary, includes a considerable number of concepts the implications of which are due to be determined only on the strength of definitive appraisal and binding together with the other concepts embraced by the Criminal Code or on the basis of our legal order generally or, ultimately, on the basis of our socialistic development. A correct application of the Criminal Code is impossible by those who ignore the laws of our social development, who do not perceive the trend of our general state policy and the live dialectics of events in all stages of our socialist progress. Without such prerequisites it is impossible to pinpoint the true context of the many concepts employed in the draft in constructing the substance of criminal offences. The tendency, then, to fix the substance of criminal offences as concretely as possible under the proposed Code should by no means be taken to denote their simultaneous petrifaction into lifeless and static moulds. The substance of criminal offences epitomizes the types of socially dangerous phenomena, life's evolutions, that is, which are subject to perpetual motion. It is for this reason that they cannot be correctly perceived if they are treated in an isolated manner, statically and divorced from the dynamics of our daily reality." ${ }^{20}$

\section{RESPONSIBILITY}

Although the Yugoslav Code defines crime as a socially dangerous act. criminal liability is not based upon the act or its consequences alone. It requires a mental element as well. Liability presupposes fault which may take the form of intent or negligence. Each of these states of mind is further subdivided. The intent is direct when the actor "was aware of his act and wanted to commit it." It is indirect when he "was aware that a prohibited consequence might result from his action or omission and consented to it." An offense is committed by negligence when the actor was aware that a prohibited consequence might result from his act but "wantonly assumed" that it would not occur or that he would be able to prevent it. And even though the actor was unaware of the possibility of a prohibited consequence resulting from his act, he is criminally negligent if, under the circumstances and "by his personal qualities" he should have foreseen such a possibility. ${ }^{27}$

If the actor's conduct resulted from a non-negligent mistake of fact the required mental element is lacking and he is exempt from criminal liability. ${ }^{23}$ On the other hand, ignorance of law, even if the offender "for justified reasons did not know that such an act was prohibited," is not a defense. In the latter case, however, the court may inflict a reduced punishment or may even release the offender from punishment. ${ }^{29}$

26. Frol, A Summary of the Draft Criminal Code, 2 New Yucoslay L. 4, 19 (1951).

27. Art. 17.

28. Art. 9.

29. Art. 10. 
Insanity is recognized as a defense and both medical and legal criteria are utilized. ${ }^{30}$ Persons who commit an offense while "in a state of lasting or temporary mental disease, temporary mental derangement or defective mental development" are not responsible if "owing to such a state of mind he was unable to understand the significance of his act (intellectual factor) or control his conduct (volitional factor)." "31 "Partial insanity" is recognized to the extent that the court may mitigate the punishment. "Measures of Security" are applied to persons found to be insane or partially insane. They are sent to special institutions for treatment. The time spent in such an institution by a partially insane person is applied on his sentence. ${ }^{82}$ Intoxication is specifically excluded as a defense. ${ }^{.38}$

\section{Preparation and Attempt}

The Special Part of the Code contains a few provisions making attempts to commit designated offenses punishable. ${ }^{34}$ Other cases are covered by general Article 16 which provides that whoever "intentionally commences committing a criminal offence but does not complete it shall be punished for attempt" only if the consummated offense be one punishable with five years of imprisonment or more. When an attempt is made to commit an offense impossible of commission under the circumstances, the court may reduce the punishment or even release the offender from punishment. ${ }^{36}$ If the actor voluntarily abstains from completing an attempted offense the court may release him from punishment. ${ }^{36}$

The Code recognizes that an attempt requires more than mere preparation. Criminal liability for preparatory acts is exceptional and exists only when explicitly denounced in the Special Part. ${ }^{37}$ These special situations are: preparing to commit offenses undermining the military and defense power of the state $;^{38}$ preparing to commit armed insurrection $;^{30}$ or assassination $;^{40}$ and preparing to destroy "social property." 41

30. Art. 6 .

31. For discussion of insanity in Soviet Law, consult Berman \& Hunt, Criminal Laze and Psychiatry: The Soviet Solution, 2 Stan. L. Rev. 635 (1950); Killian \& Arens, Psychiatry in Soviet Criminal Proceedings, 41 J. CRIM. L. \& CRImnolocy 136 (1950).

32. Art. 61.

33. Art. 6.

34. For example, infringement of inviolability of dwelling (Art. 154); manufacture and use of false measures and weights (Art. 232); blackmail (Art. 262); preventing a person in office from performing official acts (Art. 289); and destruction of official records (Art. 295).

35. Art. 17.

36. Art. 18.

37. Art. 121.

38. Art. 102.

39. Art. 104.

40. Art. 103.

41. Art. 114. 


\section{Complicity}

In most legal systems the criminal liability of persons who combine for the purpose of performing unlawful acts or join in the commission of crime is determined by the nature and extent of their participation. Different patterns of participation are conceptualized, in Anglo-American law, in doctrines dealing with principals, accessories, and conspirators. In addition, various statutes are directed against collective criminality. 42

Under the Yugoslav Code, whoever intentionally "incites" or intentionally "assists" another to commit a crime shall be punished as if he himself had committed it. ${ }^{43}$ If the instigation or assistance induces an attempt instead of a consummated offense, the "instigator and the assistant" shall be punished for an attempt. ${ }^{44}$ If the instigation is entirely unsuccessful and if the solicited offense carries a punishment of imprisonment for five years or more the "instigator" shall be punished for an attempt. ${ }^{45}$

A number of articles penalize participation in groups and combinations. Article 104 makes it a crime to take part in an armed insurrection and Article 302 punishes participation in a crowd which by joint action commits certain serious offenses. Both articles punish ringleaders and organizers more severely than mere participants.

Article 23 is a general provision concerned with the organizers of criminal associations. Whoever "creates or exploits an organization, band, conspiracy, group or some other association for the purpose of committing criminal offences shall be punished for all criminal offences resulting from the criminal plan of such associations as if he himself had committed them." According to Minister Frol, this article reflects the "attitude on the criminal liability of organisers found ... in the familiar Nuremberg sentences, thereby acquiring the undisputed international authority it enjoys today."10 This general article does not exhaust the problem of collective criminality. The Special Part of the Code contains particular provisions condemning organizational activities of various types and there are specific references to conspiracies.

It is an offense to organize a group for the purpose of committing crimes for which a punishment of imprisonment for five years or more is available. 4 Membership alone in such a group is subject to milder punishment. An in-

42. The Smith Act is a specimen. 18 U.S.C. \$23S5. It punishes

"Whoever organizes or helps or attempts to organize any society, group, or assembly of persons who teach, advocate, or encourage the overthrow or destruction of any such government by force or violence; or becomes or is a member of, or affiliates with, any such society, group, or assembly of persons, lnowing the purposes thereof."

A perceptive study of collective criminality is Arens, Nuremberg and Grons Prosecution, 1951 Wash. U.L.Q. 329.

43. Art. 19-20.

44. Art. 21.

45. Art. 19.

46. Frol, A Summary of the Draft Criminal Code, 2 NEv Yucoseny L. 12 (1951).

47. Art. 299. 
former provision exculpates from punishment a member who exposes the group. Article 117 makes it a crime to form a plot, band or any other group of persons for the purpose of committing specified offenses against the security of the state. Organizers are punishable by imprisonment for not less than five years or by death. Membership is punishable "by imprisonment." This article, as well, contains an informer clause. It is also an offense to organize a group for the purpose of committing crimes against humanity and international law. ${ }^{48}$

The general conspiracy article provides that whoever "conspires with another person to commit a particular criminal offence for which a punishment of imprisonment for five years or a heavier punishment may be pronounced by law shall be punished by detention for not more than one year." 40 Conspiring to commit specified offenses against the national security is condemned. ${ }^{50}$

\section{Sanctions}

The Italian Positivists, as indicated above, substituted the sociological categories of "socially dangerous act" and "measures of social defense" for "crime" and "punishment." This terminology was adopted by the Soviet Code which explains, in its General Section, that criminal sanctions consist of measures of social defense."2 These measures "do not pursue the object of inflicting physical sufferings or degradation of human dignity; they do not pursue the object of retribution or punishment." 33 The Vishinsky era has, however, provided a shift in emphasis. Soviet theory now recognizes a positive value in the juridical approach to crime, punishment and guilt. ${ }^{64}$

Article 3 of the Yugoslav Code declares that the purpose of punishment is : to prevent activity perilous to society; to prevent the offender from committing criminal offenses and to reform him; to exercise educational influence on other people in order to deter them from committing criminal offenses; and to influence the development of social morals and social discipline among citizens.

Seven types of punishment are prescribed by Article 24: death (shooting or hanging); imprisonment; detention; limitation of civil rights; prohibition

48. Art. 128.

49. Art. 298.

50. Art. 121.

51. Cantor, Crime and Society 215 (1939).

52. Crminal Code, R.S.F.S.R., Art. 1. These measures are of three types : judicialcorrectional, medical, or medical-educational. CRmmnat CodE, R.S.F.S.R., ART. 7. They are applied to prevent the commission of further crimes by the same offenders; to influence other unstable members of society; and to adapt the offenders to the conditions of the community life of the toiler's state. Id. ART. 9.

53. Criminal Code, R.S.F.S.R., Art. 9.

54. This shift is discussed in Starosolsky, Basic Principles of Soviet Criminal Law, 28 N.C.L. Rev. 359, 371-4 (1950) ; Berman, Principles of Soviet Criminal Lazw, 56 Y AlE L. J. 803, 808, 829 (1947); and Berman, Justice in Russia 270-80 (1950). 
to exercise a specified profession; confiscation of property; and fine. These sanctions are subdivided into principal and accessory punishments. The death penalty, imprisonment, and detention are the only forms of principal punishment. The others are accessory punishnents except the fine which may be imposed either as a principal or an accessory sanction. ${ }^{55}$

The death penalty is reserved for such grave offenses as counter-revolutionary activities, ${ }^{56}$ espionage, ${ }^{57}$ assassination, ${ }^{58}$ and sabotage. ${ }^{59}$ Even in those cases it is not mandatory and the court may choose between capital punishment and a time sentence. Furthermore, the court may always impose imprisonment for life in lieu of the sentence of death. ${ }^{60}$ In all other cases a sentence of imprisonment cannot be for less than six months nor in excess of twenty years. ${ }^{61}$ Detention cannot be for less than three day's nor in excess of five years. ${ }^{62}$ Both entail obligatory labor. Persons sentenced to imprisonment usually are assigned to physical work while those sentenced to detention are assigned to work corresponding to their technical skills and capacities. ${ }^{63}$ Detentioners are subject to a milder regime with respect to mailing and visiting privileges. ${ }^{64}$

The punishment of limitation of civil rights disables a person from taking part in public life. It includes the loss of suffrage, the right to hold office in social organizations and associations and the right to public appearance. 05 The incapacity may be permanent or for a term. It is pronounced as permanent whenever the offender is sentenced to death or when a death sentence is commuted to life imprisonment. ${ }^{60}$ It can be given for a term only when the offender is sentenced to imprisonment for not less than five years and, in exceptional cases, with sentences of two to five years. ${ }^{67}$ The punishment of prohibition to exercise a profession may likewise be permanent or for a term. Permanent proscription may be pronounced only against a person sentenced to imprisonment for not less than three years. Prohibition for a term may not be less than for three months nor in excess of five years. This punishment is imposed when the offender has abused his profession for the purpose of committing a crime or "when his further exercise of such a profession is dangerous."68
55. Art. 25.
56. Art. 100 .
57. Art. 105.
58. Art. 103.

59. Art. 115. Minister Frol justifies the retention of the death penalty as follows: "In the present situation we cannot renounce that harshest of expedients for the protection of certain particularly important social relations. Nevertheless, this type of punishment has the meaning of an exceptional and extreme measure in our penal system." Frol, $A$ Susmary of the Draft Criminal Code, 2 New Yugosmav L. 4, 14 (1951).
60. Art. 29.
61. Art. 28.
62. Art. 30.
63. Art. 54.
64. Art. 55.
65. Art. 31.
65. Art. 32.
67. Art. 33.
68. Art. 35. 
The Code gives the court a wide discretion in imposing punishment. In no case is an indiscriminate sanction required. Usually the court can choose between types as well as the duration of punishment. For example, a person found guilty of sabotage may be punished by imprisonment for not less than two years or by death $;^{69}$ negligent homicide is punishable by detention for not less than six months or by imprisonment for not more than five years ;0 and for non-payment of alimony either a fine or detention for not more than one year can be inflicted. ${ }^{71}$ In fixing the punishment the court must take into account aggravating and extenuating circumstances and especially "the degree of criminal liability, motives from which the offence was committed, the intensity of danger or injury to the protected object, circumstances under which the offence was committed, past conduct of the offender, his personal conditions and his bearing after the criminal offence."72 In imposing a fine the court must take into account the "property position" of the offender. ${ }^{73}$ An offense "in recidive" is always considered an aggravating circumstance. An offense is "in recidive" when the offender has formerly been convicted of an intentionally committed criminal offense and has within five years after completion of his sentence intentionally committed another offense for which the punishment of detention or a heavier punishment is prescribed. ${ }^{\mathbf{7 4}}$

Some of the articles in the Special Part of the Code provide that "in especially grave cases" a more severe penalty shall be inflicted. ${ }^{75}$ In these situations the heavier punishment is imposed if the offense "obtained an exceptionally dangerous aspect by being committed with particular determination, persistence or ruthlessness, or by provoking particularly grave consequences or because it was committed under especially aggravating circumstances." 76 Conversely, when there are extenuating circumstances which indicate "the possibility of the purpose of punishment being attained even with a lighter punishment" the court may impose a punishment below the limits prescribed by law or pronounce a lighter kind. ${ }^{77}$ Under some circumstances, such as a mistake of law ${ }^{78}$ or exceeding the limits of self defense, ${ }^{70}$ the court may release the offender from any punishment at all.

Articles 54 and 55 are of interest in that they deal with the rights of persons sentenced to imprisonment or detention. Although they are obliged to work, the working day is fixed at eight hours and the work week includes

69. Art. 115.

71. Art. 197.

73. Art. 39.

75. For example, Art. 218 (Disclosure of economic secrets); Art. 221 (Forgcry

and uttering counterfeit currency); Art. 253 (larency and robbery); and Art. 320 (Disclosure of official secrets).

76. Art. 41.

77. Art. 42.

79. Art. 11.
70. Art. 137.

72. Art. 38.

74. Art. 40.
78. Art. 10. 
a day of rest. Prisoners are guaranteed free medical protection, social insurance benefits in case of accident, and mail and visiting privileges.

When a person is sentenced to detention up to two years or is given a fine, the court may suspend execution of the sentence upon the condition that the offender not intentionally commit another equally grave offense within a stated period of time which may not be less than one year nor more than five years. ${ }^{80} \mathrm{~A}$ form of parole is provided in Article 56 entitled "Conditional release." An offender may be conditionally released after serving half of his sentence "if he proves by his work and behavior that he has improved himself so much that he may be expected not to commit further criminal offences." In exceptional cases where the offender particularly distinguishes himself by his work and behavior he may be conditionally released before serving half of his sentence.

In addition to articles pertaining to amnesty and pardon, ${ }^{81}$ the Code provides for "Rehabilitation." This device should be considered with Article 51 which recites that the purpose of punishment is accomplished by execution of the sentence. "Rehabilitation" provides a technique for nullifying the judgment of conviction and "unconvicting" the convicted. \$2 Its purpose is to remove the stigma which accompanies a criminal record. There are two types of rehabilitation: legal and judicial. Legal rehabilitation is limited to first offenders or those who have been "unconvicted" of a previous conviction. It is also limited to those who have been sentenced to detention for less than two years and who have not committed a new offense within a specified period after completing their sentence. Judicial rehabilitation requires a court order whereas legal rehabilitation is apparently automatic. Judicial rehabilitation is available to first offenders who have been sentenced to detention for more than two years or to imprisonment and to those who have more than one conviction. After a lapse of eight years from the completion of his sentence an offender may be judicially rehabilitated if the court feels that his behavior deserves it and if he has made restitution of the damage caused by his offense according to his ability to pay. ${ }^{83}$

\section{Liability of Minors and Applicable Sanctions}

Minors are divided into three categories: (1) Minors under fourteen; (2) Minors over fourteen who are mentally immature; and (3) Minors over fourteen who are mentally competent. A minor under fourteen is not criminally responsible and no criminal sanctions may be applied to him. ${ }^{82}$ He may, however, be committed to a guardianship agency which decides whether to leave him with his parents, place him with a guardian, or take other measures for

80. Art. 48 .

81. Art. $84-86$.

82. Art. 87.

83. Art. 89.

S4. Art. 5. 
his care and education. ${ }^{85}$ Minors over fourteen who, because of mental immaturity, are unable to understand the significance of their acts or control their conduct are not responsible. ${ }^{86}$ As to them, only "educational-reformatory measures" may be applied. They may be returned to their parents, assigned to a guardian, or be sent to an educational institution. ${ }^{87}$ Minors fourteen years of age and over who are sufficiently developed mentally to understand their acts and control their conduct are responsible. Certain punishments, however, cannot be pronounced against them: death, limitation of civil rights, and permanent prohibition to exercise a specified profession. In authorizing sanctions the Code makes an additional distinction between junior minors (14-16) and senior minors (16-18). A junior minor may be punished only if he has committed an offense for which a punishment of more than ten years of imprisonment is prescribed. ${ }^{88}$ In other cases, he is subject to educationalreformatory measures-reprimand, or commitment to an educational-reformatory home. Even though the junior minor has committed an offense carrying a punishment of more than ten years, the court may, in exceptional cases, apply educational-reformatory measures ${ }^{80}$ Senior minors must be given the prescribed punishment if they commit an offense carrying a penalty of more than five year's imprisonment. In other cases educational-reformatory metsures may be imposed. ${ }^{90}$

\section{Classification of Crimes}

Crime classification is a significant index to the values and cherished institutions of a particular society. The history of the criminal law has been one of expansion. Increasing complexities and crises in societies have been reflected in the extension of criminal and other sanctioning techniques to the realms of trade and commerce, labor-management relations, ideological conflicts, and national security. The extreme examples of this pervasiveness are the police states.

A large number of crimes known to Western European and Anglo-American law are included in the Yugoslav Code. On the other hand, the social and political system of Yugoslavia accounts for many that are not. The draftsmen of the Code consciously undertook to reflect

"the characteristics of our socialistic social and state order, which enjoys the protection of our legislation by way of determination of criminal offences and the prescription of pertinent sanctions for same ... Here it is to be noted that, on account of the interconnection and inter-dependence existing both between the natural and the social phenomena, the categories of social relationships the draft adopts as the basis of the Special Part of the Criminal Code are not, nor can
85. Art. 64.
86. Art.. 5.
87. Art. 65.
88. Art. 67.
89. Art. 68 .
90. Art. 71. 
they be, static values sharply delimitated from one another. The state order, national economy, legal order, civil service, socialistic property, etc.-all these constitute categories which, in a socialist society, are interwoven, mutually conditioned, inter-supplementary and which merge to form the dynamic socialist reality. For that reason the individual socially dangerous pursuits frequently occur as a simultaneous attack on more than one object of protection. It, therefore, depends upon the legislator's evaluation and the respective penal policy as to which category of social relationship shall be given precedence in classifying single manifestations of socially dangerous conduct actually threatening or violating a complex of social values." 01

Crimes are classified under sixteen headings: Crimes against the prople and the state; Crimes against humanity and International law; Crimes against life and body; Crimes against freedom and rights of citizens; Crimes against working relations; Crimes against honor and reputation; Crimes against personal dignity and morals; Crimes against marriage and family; Crimes against human health; Crimes against national economy; Crimes against social and private property; Crimes against general safety of persons; Crimes against justice; Crimes against public order; Crimes against official duty; and Military crimes.

Crimes against the people and the state. It is not without significance that this chapter comes first in the Special Part of the Code. It interdicts behavior directed at the foundations of the social order. The chapter is subdivided into twenty articles which define such offenses as counter-revolutionary activities, insurrection, assassination, espionage, treason, and sabotage. The punishments are severe and for most of the offenses the death penalty may be imposed although it is nowhere mandatory. And even the offenses not ordinarily carrying the death penalty are subject to it if committed "in a state of emergency, mobilization or war, or if such offences cause a heavy damage to the defensive or military power of the state or the case is otherwise especially grave."9:

Crimes against humanity and international law. This chapter is unique in that Yugoslavia is the first country to incorporate these prescriptions into a Criminal Code. It covers such offenses as genocide, war crimes, and crimes against humanity. The definition of genocide follows closely that contained in Article 2 of the Convention on the Prevention and Punishment of Geno-

91. Frol, $A$ Summary of the Draft Criminal Code, 2 New Yucoscuv L. 4, 19 (1951).

92. Art. 122. Article 119 bans the incitement of national, racial and religious hatred and dissension. The closest offense in American law is group-libel but statutes of this type have encountered constitutional objections on grounds of vagueness and as violative of freedom of expression. See, Donnelly, The Law of Defamation: Proposals for Rcform, 33 Mins. L REv. 609, 623 (1949). An Illinois statute, however, was recently upheld in People v. Beauharnais, 40 III. 512, 97 N.E. 2d 343, cert. granted, 342 U.S. 809 (1951). 
cide. ${ }^{93}$ The other crimes are based largely upon the definitions contained in Article 6 of the Charter of the International Military Tribunal, commonly known as the Nuremberg Charter. ${ }^{04}$

Crimes against life and body. The traditional crimes of homicide, infanticide, bodily injury, suicide, and abortion are defined in this chapter. Intentional homicide is punishable by imprisonment for not less than five years. The minimum is raised to ten years when committed under aggravated circumstances "in a cruel or surreptitious manner or in a manner endangering the life of more persons, or for the purpose of benefit, or the purpose of committing or concealing another criminal offence, or from other base motives," or when several persons are killed.95 "Instant homicide," which is defined as a killing in a state of strong rage provoked by attack or "heavy insult" is subject to imprisonment for not more than ten years. ${ }^{.8}$ Homicide by negligence is punishable by detention for not less than six months or by imprisonment for not more than five years. ${ }^{07}$

Inciting another to commit suicide or assisting its commission or attempt is punishable by detention for not less than six months or by imprisonment for not more than five years. ${ }^{08}$ Instigating the suicide of a minor or a mental defective entails a heavier penalty. And one who cruelly or inhumanly treats one "placed in relation of subordination or dependence towards him and in consequence of such treatment that person commits suicide, the former shall be punished by detention for not less than three months or by imprisonment for not more than five years."

Article 147 is a so-called Good Samaritan provision typical of civil law codes. One who "fails to offer help to a person exposed to immediate danger of life, although he was able to do so without any danger to himself or any other person, shall be punished by detention for not more than one year."

Crimes against the personal freedom and rights of citizens. This chapter utilizes criminal sanctions as a technique for protecting constitutional guarantees. It is a crime to deny or limit, because of national, racial or religious differences, the constitutional rights of citizens. ${ }^{100}$ Coercion is prohibited. ${ }^{101}$

93. See, Comment, Genocide: A Commentary on the Convention, 58 YALE L. J. 1142, 1157 (1949). Also consult Schroeder, International Crime - ANd tHE U. S. ConstiTutron (1950); and McDougal \& Arens, The Genocide Convention and the Constitulion, 3 VAND. L. Rev. 683 (1950).

94. The charter is set out in Dession, Criminal Law, Administration and Punlic ORDER 36 (1948).

95. Art. 135 .

96. Art. 136.

97. Art. 137.

98. Art. 139.

99. A curious provision of the Code is A.rt. 138 dealing with infanticide. It subjects to detention for not less than six months a mother who kills her child during childbirth or immediately thereafter while she is still "in the state of derangement provoked by childbirth." If reference is being made to a post partum psychosis then the general article on insanity (Art. 6) should relieve the mother from criminal liability.

100. Art. 148.

101. Art. 149. 
It is an offense to deprive a person of his freedom of movement. ${ }^{102}$ Officials who extort statements from an accused or witness ${ }^{103}$ or use their position to mistreat others in any way "offensive to human dignity" are punishable. ${ }^{10-2}$ Other offenses are: Breaking into a dwelling without authorization; ${ }^{105}$ unlawful search;106 violating the secrecy of letters and other parcels;10i disclosing professional secrets; $;^{108}$ preventing or disturbing a public assembly; $;^{100}$ violating the right of suffrage ${ }^{110}$ preventing a citizen from filing a complaint or petition; ;11 $^{11}$ preventing the publication and distribution of books, magazines, newspapers and other printed matter $;^{112}$ and violating copyright ${ }^{113}$ or patent rights. ${ }^{114}$

Crimes against work relations. A socialist state considers work an important social value. For that reason, the Code attaches special importance to work relations and erects a separate category of criminal offenses for invasions of this relationship. It is a crime not to observe the regulations dealing with salaries, working hours, annual leave, ${ }^{110}$ and social insurance. ${ }^{110}$ The failure of those responsible to comply with safety and hygienic measures constitutes a social danger of sufficient magnitude to be encompassed by the Code.117

Crimes against honor and reputation. Truth is a defense to a prosecution for defamation. Belief in the truth of a false statement is likewise a defense providing the error was "excusable" but the defendant may be convicted of the lesser offenses of "insult" or "slight through reproach."118 Article 178 authorizes an interesting sanction in defamation cases. At the request of a plaintiff who has been defamed in the press or by radio, the court may require that its judgment of conviction be punished "in part or in extenso" in the same manner as the offending statement at the cost of the defendant.

Crimes against personal dignity and morals. This chapter defines the crimes of rape, seduction, obscenity, white slavery, and sexual deviations. It also contains an answer to the challenging question whether the exploitation of a woman's economic dependence for sexual purposes should be made a crime and treated like rape. ${ }^{119}$ Article 182 provides that whoever "through misuse

102. Art. 150.

103. Art. 151.

104. Art. 152.

105. Art. 154.

105. Art. 155.

107. Art. 156.

108. Art. $15 \%$.

109. Art. 158.

110. Art. 159.

111. Art 161.

112. Art 162.

113. Art. 163.

114. Art. 164.

115. Art. 165 .

116. Art. 166.

117. Art. 167.

118. Art. 169.

119. The Soviet and Swiss Codes also give an affirmative answer to this question. Even though the idea is accepted, it is difficult to find a suitable legislative formula. The Criminal Code of the Russian Republic punishes "coercion" of a woman "by any persan on whom she is dependent materially or by reason of her employment." Carariss. Cons, R.S.F.S.R., ART. 154. The Swiss Code provides that "whoever influences a woman to copulate with him by abuse of her emergency or her dependency caused through an off- 
of his position procures a female person subordinated or dependent upon him to have carnal knowledge, shall be punished by detention for not more than three years." The penalty for forcible rape is imprisonment for not more than eight years. If the victim received grievous bodily injury or was killed the punishment shall not be less than two years. ${ }^{120}$ Carnal knowledge with an infirm person or a minor under fourteen years of age is punishable by detention or by imprisonment for not more than five years. ${ }^{121}$

Crimes against marriage and family. Included in this chapter are the crimes of bigamy, abduction, incest, neglect and mistreatment of children, and nonpayment of alimony. The incest article is of special interest for two reasons: (1) It is confined to intercourse between near blood-relations, i.e., "a relative by blood in direct lineage or with brother or sister"; and, (2) the mildness of the penalty, namely, detention. ${ }^{122}$

Crimes against human health. Spreading an infectious disease ;123 communicating a venereal disease $;^{\mathbf{1 2 4}}$ unlawfully practicing medicine ${ }^{\mathbf{1 2 0}}$ improperly manufacturing, selling, and distributing medicines and drugs $;^{120}$ and polluting drinking water ${ }^{127}$ are some of the offenses condemned in this chapter. The penalty for practicing medicine without proper medical training is detention for not more than one year and by a fine. The penalties for the other offenses are similarly mild.

Crimes against national economy. In a planned economy where the state is the chief organizer and director of economic life, the state will seek to enforce its policies concerning the production and distribution of goods by resorting to criminal sanctions. This chapter is one of the most important and far reaching in the Code. It contains thirty-six separate articles-more than any other chapter. Even such familiar crimes as counterfeiting, false measuring, infesting livestock and plants with contagious diseases, and unlawful hunting and fishing take on a different orientation when considered offenses against national economy. A series of articles applies to the "responsible person in a state enterprise, cooperative or any other social enterprise." Careless or conscious neglect of duty ;28 the manufacture of unusable products $;^{128}$ the distribution of deficient products $;^{130}$ entering into detrimental contracts $;{ }^{131}$ favoring certain consumers over others $;^{\mathbf{1 3 2}}$ and bartering ${ }^{103}$ are

cial or an employment relation or through other similar situation, shall be confined in tho prison." Swiss Federal Criminal Code, Art. 197.
120. Art. 179.
121. Art. 180, 181.

122. Art. 198. For a thoughtful discussion of the crime of incest, see MaNNHens, Criminal Justice and Soctal Reconstruction 77 (1946).
123. Art. 199.
124. Art. 201.
125. Art. 205.
126. Art. 205-209.
127. Art. 211.
128. Art. 213.
129. Art. 214.
130. Art. 215.
131. Art. 213-217.
132. Art. 228.

133. Art. 229. 
proscribed. Other articles concern the disclosure of economic secrets; ${ }^{131}$ trafficking in real estate without permission; ${ }^{135}$ destroying or damaging dwellings and business buildings; $;^{136}$ forgery and counterfeiting ; ${ }^{137}$ falsely marking goods $;^{138}$ price violations; $;^{139}$ hoarding and speculation $;^{140}$ failing to effect obligatory deliveries of agricultural products to the state; $;^{141}$ failing to cultivate land and raise livestock; $;^{142}$ destroying or damaging agricultural equipment, crops, or cattle $;^{143}$ undermining cooperatives:144 and devastating forests. ${ }^{145}$

Offenses against social and private property. The traditional offenses against property of larceny, robbery, embezzlement, fraud, ${ }^{140}$ extortion, blaclimail and receiving stolen property are included in this chapter. Although the articles defining these crimes make no distinction between private and social property, an offense against social property ${ }^{\mathbf{1 4 7}}$ may indeed evole a more severe sanction. First of all, the behavior may fall within the ambit of an offense defined in the chapters on offenses against the people and the state or against the national economy. Also, specific provision is made for more severe punishment when the subject of the offense is social property. For example, the usual penalty for larceny is detention for not less than three years or imprisonment for not more than five years. ${ }^{148}$ However, if the property taken was a machine, technical equipment, work tools from a factory, mine or workshop, military equipment, cattle, or provisions designed for distribution to citizens, the penalty is imprisonment for not more than twelve years and the offense is deemed "Grave Larceny." 140 In addition, article 255 dealing with plunder overlaps the "Grave Larceny" article. It provides that when property taken by larceny or embezzled by a public officer consists of "provisions, industrial products, ration cards for food or industrial products, or any other object of social property of particular significance for national economy or supply of citizens, and the quantity of stolen or embezzled objects is so great

134. Art. 218.

135. Art. 219.

137. Art. 221, 222.

136. Art. 220.

139. Art. 227.

138. Art. 225.

140. Art. 233.

141. Art 236. Notwithstanding the criminal sanction, Yugoslav authorities are experiencing difficuties in obtaining deliveries of grain quotas from collective farms. The primary source of trouble is "the attitude of the peasants and the appeasement of the peasants by the local authorities." N.Y. Times, Dec. 31, 1951, p. 5, col. 1 .

142. Art. 238.

144. Art. 240, 241.

146. The fraud article (Art. 258) is interesting in that it makes the severity of the sanction depend upon whether the offender was an amateur or whether be committed the offense "as a professional practice."

147. Social property is defined in the General Part of the Code as "general people's property, cooperative property and property of social organizations." (Art. 99(5)). Article 267 accords the same protection to property "entrusted to the State, cooperative or a social organization or kept by them upon any legal basis."

148. Art. 249.
149. Art. 250. 
that it obviously demonstrates disregard towards the community" the offender shall be punished by imprisonment for not less than two years. And if the plunder "causes particularly grave consequences for national economy or supply of citizens, or the offence was committed under circumstances rendering it exceptionally grave, especially if it was committed by a group of persons or a band, the offender shall be punished by imprisonment for not less than ten years or by death."

Crimes against the general safety of persons. This chapter makes it criminal to endanger life or property by fire, flood, explosions, and in conducting industrial and construction projects. Negligence as well as intent is a basis for liability.

Crimes against justice and crimes against public order and legal intcrcourse. These chapters apply to a wide range of offenses many of which are unrelated. Offenses against justice include the failure to notify the authorities of the preparation of criminal offenses or to notify them of committed offenses; ${ }^{100}$ aiding an offender after the commission of a crime ${ }^{161}$ making false criminal charges $;^{\mathbf{1 5 2}}$ perjury and false swearing $;^{\mathbf{1 5 3}}$ and enabling prisoners to escape. ${ }^{\mathbf{1 0 4}}$

Some of the offenses against public order and legal intercourse are: preventing an official from performing his duties $;^{165}$ inciting others to resist or disobey legal decisions or state regulations; ; $^{160}$ refusing to obey an order to disperse $;^{\mathbf{1 5 7}}$ gambling as a professional practice ${ }^{\mathbf{1 5 8}}$ pettifoggery $;^{\mathbf{1 5 0}}$ disturbing religious rites; ${ }^{\mathbf{1 6 0}}$ and illegally possessing arms and explosives. ${ }^{101}$

Crimes against official duty. Officials are subject to a high degree of criminal responsibility in the performance of their duties. ${ }^{102}$ Misuse of official position is punishable by cletention for not more than three years. ${ }^{103}$ Nonfeasance as well as the careless performance of official duties may result in detention for not more than six months and if substantial damage results to the state or the rights of citizens the detention may be increased to four years. ${ }^{164}$ Other provisions penalize bribery $;^{\mathbf{1 6 5}}$ embezzlement ${ }^{\mathbf{1 0 6}}$ and the disclosure of official secrets. ${ }^{167}$
150. Art. 279, 280.
151. Art. 281.
152. Art. 282.
153. Art. 283.
154. Art. 287, 288.
155. Art. 289.
156. Art. 291.
157. Art. 292.
158. Art. 305.
159. Art. 310.
160. Art. 313.
161. Art. 301.

162. For a discussion of the abuse of power by officials in a state which proclaims its socialist character, see Hazard, Socialism, Abuse of Power, and Sovict Law', $50 \mathrm{Cot}$. L. REv. 448 (1950), and Hazard, Sozict Socialism and Embezalentent, 26 WASr. L. REv. 301 (1951).
163. Art. 314.
164. Art. 317.
165. Art. 325.
166. Art. 322, 323.
167. Art. 320. 
Military crimes. Military crimes are included in the criminal code. ${ }^{103}$ These crimes are typical of articles of war generally. Except for such offenses as assaulting a military person ;169 failure to report for military service $;^{\mathbf{1 7 0}}$ and failure to supply cattle or vehicles for military use, ${ }^{171}$ only military personnel are subject to punishment for military crimes. Jurisdiction is in the regular courts. Minister Frol explained the inclusion of military crimes in the criminal code as follows:

"It is customary to enact a separate criminal law for military criminal offences, but we are not adopting that practice since the prescriptions of the General Part of the Criminal Code must primarily apply to offences of this kind as well. Hence, if the military criminal offences were to be dealt with by a separate law this would always entail the utilization of two laws in the relevant proceedings. However, aside from this purely technical reason for the inclusion of military criminal offences into the general criminal code, there also arises a reason of principle to favour this which is that our armed forces are a component part of our people. It is comprehensible, necessary and justified that separate provision should be made for criminal offences against the armed forces for there exists a whole range of specific socially dangerous pursuits aimed against the established order of our Services, against their stability and combat capacity. The provisions made in a separate chapter of the Criminal Code in regard to such criminal offences reflect consideration for the characteristics of military service, showing at the same time, though, that no line is drawn between the members of our armed forces and our other citizens and that a uniform criminal code applies to all of them."172

\section{CONCLUSION}

This examination of the Yugoslav Criminal Code has necessarily been more descriptive than comparative and analytical. A comparative study by one not familiar with the culture under scrutiny is likely to result in sterile conceptualistic comparisons. ${ }^{173}$ Identical propositions of law often bear quite dif-

168. Military crimes are also included in the Russian Criminal Codes. Berman, Principles of Soviet Criminal Lazo, 56 YALE L. J. 803, 834 (1947).

169. Art. 331.

170. Art. 340, 341.

171. Art. 344.

172. Frol, $A$ Summary of the Draft Criminal Code, 2 NEw Yucoslav L 4, 23 (1951).

173. Familiarity with the culture does not in itself assure a meaningful study. The investigator should operate within a systematic framework of inquiry which attempts to formulate the basic concepts and hypotheses of the legal system. Recognition should be given not only to the empirical legal propositions but to the value judgments as well.

A significant framework for communicating the present postulates, hypotheses, and findings of political science is developed in LAssweil \& KAPLAN, Power AND Sociens: (1950). 
ferent overtones in different legal systems. The variation is often explainable in terms of the respective traditions and values underlying the systems. Furthermore, in every society there is a gulf between the law as written and the law as practiced. A meaningful comparative study should take account of institutional arrangements and practices. Not only should such variables as personnel, administration and procedure be assessed, but an investigator should realize that in authoritarian systems there is frequently a dual administration of law. For instance, the political police and other special agencies may be immune from the restrictions of the criminal code. ${ }^{174}$

Nevertheless, certain observations are salvable from even a descriptive inquiry. The first is the pervasive character of the Yugoslav Code. Although characteristic of a tightly planned economy this trait is by no means peculiar to it. The United States has witnessed an ever growing resort to criminal sanctions as mechanisms for maintaining and extending public order in the arenas of trade and commerce, labor-management relations, national security, and ideological conflicts. And, with us, the criminal law is expansive in another respect. While our compilations of criminal laws generally deal only with the common crimes and their penalties there are numerous other criminal provisions lodged elsewhere. Regulatory statutes, in particular, authorize criminal sanctions either as an alternative or for use in conjunction with civil ones.

Notions of "social danger" and "measures of social defense" are not entirely foreign to criminological thought in this country. Punishment is no longer discussed exclusively in terms of vengeance, retribution and expiation. We are beginning to speak of social protection through deterrence and rehabilitation, when possible, and otherwise through incapacitation. ${ }^{175}$ The criminal law is no longer regarded as primarily the protector of individual rights and interests. Its function is also the protection of the rights and interests of the community. Furthermore, we are beginning to look upon the criminal law

174. The Soviet dual system has been described as follows:

"Entirely outside of this judicial hierarchy stand the Ministry of the Interior and the Ministry of State Security. Let the element of sabotage or counterrevolution be introduced, and the Ministry of the Interior, through a 'Special Board,' talics over. Here the trial is administrative and secret. Judging from reports of those who have experienced these trials, defense counsel are not allowed, there is no right of appeal, and conviction is almost certain, regardless of the truth of the charges."

Berman, Justice in Russia 84 (1950). Also consult, Starosolsky, Basic Principles of Soviet Criminal Law, 28 N.C.L. Rev. 359, 360 (1950) ; HazArd, Sovier LAw ANd Its Assumptions in Ideological Differences and World Order 204 (Northrop ed. 1949).

A similar practice prevailed in Nazi Germany. Kirchheimer, Criminal Laze in National Socialist Germany, 8 Studies in Philosophy \& Social Sci. 444, 452-6 (1939).

175. See Dession, Justice after Conviction, 25 Cons. B. J. 215 (1951). 
as a creative social force, as a technique for maximizing the values of our society. ${ }^{176}$

The definitions of the familiar crimes in Yugoslav law differ only slightly from those of Anglo-American law. However, the penalties prescribed for these crimes are less severe than in the United States. The numerous provisions in the Yugoslav Code dealing with group crimes manifest a conception of group criminality which closely approaches the Anglo-American law of conspiracy. ${ }^{177}$

There are several interesting deviations from Anglo-American law. One is the treatment of sexual intercourse induced by economic coercion as a form of rape. Force is an essential element in the American lav of rape. The force need not be physical but may be supplied by threats or, in some cases, by fraud. The threats must be of death or great bodily harm. Economic intimidation is not sufficient. ${ }^{178}$ For a number of reasons, the range of sex offenses should not be broadened in this country. In the first place, Professor Kinsey and his associates have revealed the high incidence of illicit sexual behavior in the American male. Their study documents the hypocritical disparity between private acceptance of and participation in this behavior and the public rejection of it. ${ }^{179}$ The lack of witnesses to alleged sex offenses makes them singularly susceptible to false complaints which, because of judge and jury bias in favor of the complaining witness, are frequently sustained. Too, what appears on the surface to be a straightforward and convincing story is often the fabrication of a disturbed personality. ${ }^{180}$ The complainant may be motivated by revenge, a desire for notoriety, or her false complaint may be an attempt to escape public censure for known illicit sexual behavior. Another type of complainant is the hysteric for whom the false charge serves a wishfulfilment function. ${ }^{181}$ The present rules of evidence hinder rather than aid a proper inquiry into the veracity of complaints of sexual misconduct. Until they are liberalized to permit adequate probing of the personality of com-

176. This point is developed in Mannherar, Crisinal Justice and Social ReCONSTRUCTION 195, 259-70 (1946).

177. Mr. Justice Jackson's dictum that the concept of conspiracy "does not commend itself to jurists of civil law countries" [Krulewitch v. United States, 336 U.S. 440, 450 (1949) ] may be correct conceptualistically but more careful studies have shown that the prosecution of similar combinations is not unknown to the civil law. Wagner, Consfiracy in Civil Law Countries, 42 J. Crm. L. \& Canmology 171 (1951); Arens, Nuremberg and Group Prosecution, 1951 WASH. U. L. Q. 329.

178. Submission under compulsion of parental command has been held forcible. State v. Dawson, 88 S.C. 225,70 S.E. 721 (1911).

179. Kinsey, Poareroy \& Martin, Sexual Behamos in the Husan Minie (1948).

180. The pioneer study in this field is Healy, Patrological Lying, Accusatron, ANd Swinditing (1905).

181. For a discussion of the hysteria neurosis, see Noyes, Modern Cunnichr PSYchiatry 283 (3d ed. 1949). Also, see 3 Wigarore, Evidence $\$ 9243$ (1940). 
plaining witnesses, sex crimes should not be extended but narrowed in scope. ${ }^{182}$

Good Samaritan statutes raise the basic question whether the criminal law should compel active benevolence between man and man. ${ }^{183}$ In AngloAmerican law a person who is under no "legal duty" to render care and attention to another, whatever may be his ethical duty, is not guilty of manslaughter if death results from his neglect. Absent a legal duty there is no criminal omission. ${ }^{184}$ Nevertheless, there is a substantial body of criminal law which brings various omissions within the scope of penal liability. The least questioned concerns the immediate family relationship. Nor have the courts had any difficulty in finding a "legal duty" arising out of such traditional relationships as master and servant, guardian and ward, captain and crew, nurse and patient, jailer and convict. In these there is no uncertainty as to what duties are required nor upon whom the duty rests. Judicial extension of these categories is deterred by the understandable reluctance of the courts to subject a "stranger" to the same penalty that would be imposed on a close relative. Legal reform must come, therefore, through legislation providing an entirely different category for "strangers" and prescribing lighter penalties. Livingston proposed that one should be considered guilty of homicide who neglects to save life when he could do so "without personal danger,

182. The evidentiary problem is discussed in Note, Psychiatric Aid in Evaluating the Credibility of a Prosecuting Witness Charging Rape, 26 INv. L. J. 98 (1950); State v. Wesler, 137 N.J.L. 311, 59 A.2d 834 (1948), 39 J. CrIm. L. \& Criminology 750 (1949); Yessen v. State, 228 Ind. 316, 92 N.E. $2 d 621$ (1950). A more general evaluation is Comment, Psychiatric Evaluation of the Mentally Abnormal Williss, 59 YaLE L. J. 1324 (1950).

183. Bentham supported his proposal for a Good Samaritan law by the following hypothetical cases: "A woman's head-dress catches fire: water is at hand: a man, instead of assisting to quench the fire, looks on, and laughs at it. A drunken man, falling with his face downwards into a puddle, is in danger of suffocation: lifting his head a little on one side would save him: another man sees this and lets him die. A quantity of gunpowder lies scattered about a room: a man is going into it with a lighted candle: another, knowing this, lets him go in without warning. Who is there that in any of these cases would think punishment misapplied?" Benthan, Introduction to the Principles of Morals and Legislation, c.17, $\$ 19$ at 323 , n. 1 (1879).

184. The tautological character of this aphorism is exposed in HALL, GeNeral. Principles of Criminal Law 250 (1946).

The French Code contains a provision similar to the Yugoslav article. In its first decision under this section, the highest court of France recently held it to apply to a physician who failed to answer an emergency call, although his acquittal was affirmed on the ground that he had not been apprised of the peril with sufficient certainty to make his failure "voluntary." Note, 63 HARv. L. REv. 886 (1950).

The Yugoslav Code has a separate article dealing with physicians. Article 204 prom vides that a "physician who contrary to his professional duty refuses to offer medical assistance to a sick person whose life is directly endangered, shall be punished by fine or by detention for not more than two years." 
or pecuniary loss."185 And Ames suggested a similar rule. ${ }^{180}$ Beginnings have been made by statutes requiring motorists ${ }^{18 i}$ and railroad employees to aid persons injured by them, and a Federal statute ${ }^{188}$ requires the master of a vessel "so far as he can do so without serious danger to his own vessel, crew, or passengers," to "render assistance to every person who is found at sea in danger of being lost."

Prosecutions for criminal libel are more frequent on the Continent than in the United States. ${ }^{180}$ This perhaps accounts for Article 178 of the Yugoslav Code which authorizes a court to require publication of its judgment of conviction in libel cases. In a similar vein are the press laws of many European and South American countries which supplement the civil action for libel by permitting a person attacked in the press to publish an immediate reply in the offending publication. ${ }^{100}$ In the United States it is a brave man indeed who launches a libel suit. Not only is vindication hampered by inadequate and obsolete doctrine, but he can rarely match the financial resources of newspaper or radio defendants in pre-trial preparation and in retaining expert counsel. And even though he should win, the judgment in his favor seldom comes to the attention of the people who read or heard the libel and who still remain under the impression created by the offending publication. He is met by a conspiracy of silence on the part of the press since libel suits against newspapers, by professional courtesy, are rarely reported. Elsewhere, I have urged the adoption of the right of reply in this country as an alternative for an action for libel. ${ }^{101}$

The Yugoslav government has not only ratified the Convention on Genocide ${ }^{192}$ but has implemented it by incorporating the crime with severe penal-

185. Livingston, Code of Crimes and Punishaments, Art. 484 (1833).

186. Ames, Law and Morals, 22 HARv. L. REv. 9\%, 113 (1908): "One who fails to interfere to save another from impending death or great bodily harm, when he might do so with little or no inconvenience to himself, and the death or great bodily harm follows as a consequence of such inaction, shall be punished criminally and shall make compensation to the party injured or to his widow and children in case of death."

187. For example, Cons. Gen. Stat. (1949 Rev.) \$ 2410 provides:

"Each person operating a motor vehicle who knowingly causes injury, whether or not resulting in death, to any other person... shall at once stop and render such assistance as may be needed..."

A penalty of a fine of not less than $\$ 50$ nor more than $\$ 100$ or imprisonment for not more than one year or both may be imposed.

188. 46 U.S.C. $\$ 728$. A fine not exceeding $\$ 1000$ or imprisonment not exceeding two years, or both, may be inflicted.

189. Riesman, Democracy \& Defamation, 42 CoL L. Rev. 727, 745, (1942).

190. These laws are discussed in Donnelly, The Right of Reply: An Altcriotice to an Action for Libel, 34 VA. L. REv. S67 (1948).

191. Ibid.

192. Pertinent portions of the Convention text are printed as an appendix to Comment, Genocide: A Comstentary on the Convention, 58 Y YLE L. J. 1142, 1157 (1949). 
ties into its Criminal Code. Conscious of the legal shortcomings of the Nuremberg trial which held that only group extermination carried on during the war was punishable, the United Nations General Assembly unanimously adopted this Convention. This Convention has not been ratified by the United States much to the satisfaction of the American Bar Association and the Editor-inChief, Mr. George A. Finch, of the influential American Journal of Intornational Laze. ${ }^{193}$ At its September, 1949, meeting the House of Delegates of the Bar Association solemnly resolved "that the suppression and punishment of Genocide under an international convention to which it is proposed the United States shall be a party involves important constitutional questions" and "that the proposed convention raises important fundamental questions but does not resolve them in a manner consistent with our form of Government." It recommended "that the convention on Genocide now before the United States Senate be not approved as submitted. ${ }^{104}$ Able scholars have demonstrated the vacuousness of these fulminations. ${ }^{105}$ The real issue is whether the United States has the moral courage to assume leadership in this humanitarian endeavor and whether it will avail itself of this opportunity to reaffirm before the world its dedication to fundamental human dignity.

A feature of the Yugoslav Code which deserves serious consideration in this country is "Rehabilitation." This device which erases a criminal conviction is available following both the service of sentence and a specific period during which no new offense is committed. This raises a basic question. Who is a criminal? The most simple answer is: A person who commits a crime. But this merely raises additional questions. How long is a person who commits a crime a criminal? Is it only while he is committing the crime, until he has "paid the penalty," or for the remainder of his life? These questions are difficult to answer only because the word "criminal" is used to stigmatize law violators and because it is applied only to those who are ostracized by society. In this country, a man who has committed a crime and has been convicted usually remains a criminal all his life. Even an innocent person who has been erroneously convicted must ordinarily resort to a pardon for relief if the term of court has expired and if the time for filing a motion for a new trial has lapsed. ${ }^{196}$ But a pardon is inadequate since it does not affect

193. See 43 AMr. J. INT'L L. 732 (1949). In a lead editorial entitled "The Genocide Convention," Mr. Finch approves and attempts to justify the action of the Bar Association.

194. The resolution appears in A.B.A. Section of IntERnational and Comparative Law, Report and Recommendations (1949) and in A.B.A. Special Committere on PEAce and Law Througr United NatTons, Report (1949).

195. See, e.g., McDougal \& Arens, The Genocide Convention and the Constitution, 3 Vand. L. Rev. 683 (1950); Schroeder, International Crime and the U.S. ConSTITUTION (1950).

196. See, United States v. Kaplan, 101 F.Supp. 7 (S.D.N.Y. 1951).

Although the Advisory Committee on the Rules of Criminal Procedure recommended that there be no time limitations where a motion for new trial is based on newly dis- 
the record fact of guilt. Despite pardon, a conviction may still be the basis for discrediting a witness, ${ }^{197}$ disbarring an attorney, refusing an application for naturalization, or withholding a license to engage in a business. And the New York Court of Appeals reluctantly applied an "habitual criminal" statute to a person pardoned for innocence. ${ }^{198}$ Since the courts usually fail to distinguish between pardons for innocence and pardons for other reasons the foregoing disabilities apply, $a$ fortiori, in the latter case.

A few jurisdictions have attempted to improve the lot of the wrongfully convicted by providing for indemnity ${ }^{100}$ and a recent New York statute ${ }^{200}$ provides that when a pardon by the governor is based on a finding of innocence from evidence discovered after the judgment of conviction and after the time for a motion for a new trial, upon motion the judgment of conviction must be set aside and the indictment dismissed by the court in which the defendant was convicted. This "shall place the defendant in the same position as if the indictment... had been dismissed at the conclusion of the trial by the court because of the failure to establish the defendant's guilt beyond a reasonable doubt.'201

In this country, a guilty person, as well as an erroneously convicted one, may obtain a pardon. ${ }^{202}$ Some legal writers have suggested that a distinction

covered evidence, Rule 33 of the Federal Rules, as promulgated by the Court, limits the time to two years after final judgment. The writer can suggest no sufficient reason why relief against erroneous criminal convictions should be barred by time limitations.

197. Although the original conviction may be used to impeach a witness, the pardon may be introduced for purposes of rehabilitation, the credibility of the witness being left to the jury. United States v. Richards, 91 F.Supp. 323 (D.D.C. 1950), 25 TuLAre L. REv. 281 (1951), aff'd, 192 F.2d 602 (D.C.Cir. 1951).

The Yugoslav Code provides that a pardon erases the conviction. (ATt. 86).

198. Prisament v. Brophy, 287 N.Y. 132, 38 N.E. 2d 468 (1941). See also Grosedose v. Plummer, 106 F.2d 311 (9th Cir. 1939) (pardon on grounds other than innocence). And see Note, Effect of Pardons for Innocence under "Habitual Crinsisal" Stolutes, 51 YAIE L. J. 699 (1942).

199. See, e.g., 28 U.S.C. $\$ \$ 1495,2513$. For the history of this and similar state statutes, see Borchard, State Indennsity for Errors of Criminal Justice, 21 B.U.L. Rev. 201 (1941) ; Borchard, Convicting the Innocent (1932). The operation of the Nev York statute is reviewed in 21 N.Y.U.L.Q. REv. 422 (1946).

200. N.Y. Laws 1946, c.60., N.Y. Conz of Crnss. P. § 697 (McKinney, 1951 Cum. Supp.).

201. A Note in 59 HARv. L. REv. 1174 (1946) suggests that this statute may encounter constitutional difficulties as violating the principle of separation of powers. A related question is the validity of legislative pardons. On the latter, see Weihofen, Legislatiz: Pardors, 27 CALIF. L. REv. 371 (1939); and Radin, Legislatizu Pardors: Arother View, 27 CAIIF. L. REv. 387 (1939).

202. An offender may apply for a pardon after completing his sentence for the purpose of restoring those rights which were lost as a result of the conviction. Rule 16 of the Rules Governing Petitions for the Executive Clemency, approved January 19, 1946, provides that a petition for a presidential pardon after completion of a sentence will not 
be made between a pardon for innocence and a pardon for other reasons. In the former case the pardon should "blot out" guilt and make the recipient "as innocent as if he had never committed the offense." 203 In the case of a pardon for other reasons, they urge, the fact of the crime should not be obliterated since guilt is conceded.204

The Yugoslav rehabilitation is for the guilty. The closest approach to it in this country is Section 1203.4 of the California Penal Code ${ }^{205}$ which provides, in substance, that where a defendant has satisfactorily completed the period of probation, the information against him may be dismissed, or if he has pleaded guilty, the plea shall be changed to not guilty; and the defendant "shall thereafter be released from all penalties and disabilities resulting from the offense or crime of which he has been convicted." However, "in any subsequent prosecution of such defendant for any other offense, such prior conviction may be pleaded and proved and shall have the same effect as if probation had not been granted or the accusation or information dismissed." Thus, satisfactory completion of probation wipes out the conviction. However, if the defendant subsequently commits an offense, the earlier conviction is revived. For example, the conviction is reinstated and counts as a prior conviction if the defendant is subsequently convicted $;^{200}$ if he is subsequently prosecuted for another offense and takes the witness stand, the former con-

be referred for reports unless the petitioner has been released from custody not less than three years and is not on parole or probation. A longer period may be required depending on the nature of the offense and the character of the petitioner. In cases of perjury, for example, a period of five years after release is usually requircd. Rule 16 is cited in United States v. Richard, 91 F.Supp, 323, 324 n. 3 (D.D.C. 1950), aff'd, 192 F.2d 602 (D.C.Cir. 1951).

203. Ex Parte Garland, 4 Wall. 333, 380 (U.S. 1866).

204. Weihofen, The Effect of a Pardon, 88 U. PA. L. Rev. 177 (1939).

205. The complete text is as follows:

"Every defendant who has fulfilled the conditions of his probation for the entire period thereof, or who shall have been discharged from probation prior to the termination of the period thereof, shall at any time thereafter be permitted by the court to withdraw his plea of guilty and enter a plea of not guilty; or if he hats been convicted after a plea of not guilty, the court shall set aside the verdict of guilty; and in either case the court shall thereupon dismiss the accusations or information against such defendant, who shall thereafter be relcased from all penalties and disabilities resulting from the offense or crime of which he has been convicted. The probationer shall be informed of this right and privilege in his probation papers. The probationer may make such application and change of plea in person or by attorney, or by the probation officer authorized in writing; provided, that in any subsequent prosecution of such defendant for any other offense, such prior conviction may be pleaded and proved and shall have the same effect as if probation had not been granted or the accusation or information dismissed." Cal. Penal Code, \$ 1203.4 (Deering, 1951).

206. People v. Hainline, 219 Cal. 532, 28 P.2d 16 (1933); People v. Barwick, 7 Cal. 2d 696, 62 P.2d 590 (1936). 
viction may be used for impeachment purposes; $; 07$ the provision is expressly made non-applicable in disbarment proceedings; $; 208$ and the conviction must be considered in suspending or revoking a driver's license. ${ }^{200}$ And a recent decision held that the state medical board was authorized to suspend a physician's license for "unprofessional conduct" on the ground that Section 1203.4 did not wipe out the conviction of an offense involving moral turpitude. Suspension from a profession was not deemed a penalty or disability released by the statute. ${ }^{210}$

The California statute has been so riddled with exceptions as to emasculate its value as an unconvicting device. Such a statute, without exceptions, administered by conscientious courts and adequate probation personnel would serve a useful and humanitarian purpose. Why shouldn't an offender be given a clean slate if he has been able to readjust to civilian life and has been a law-abiding citizen for a reasonable period?

Only an examination of the actual operation of the Yugoslav Criminal Code will disclose its real value to that country. In any event many of its provisions, whatever the results there, are worthy of careful consideration for possible application to American problems in criminal law.

207. People v. James, 40 Cal. App. 2d 740, 105 P.2d 947 (1940). However, if he appears as a witness in other litigation and not as a defendant, the former conviction apparently cannot be used. People v. Mackey, 5S Cal. App. 123, 208 Pac. 135 (1922).

208. CaI. Bus. Prof. Code. $\$ 6102$, codifying In rz Phillips, 17 Cal. 2d 55, 109 P.2d 344 (1941).

209. CaL Ver. Code $§ 309$ (Deering, 194\$).

210. Meyer v. Medical Examiners, 34 Cal. 2d 62, 206 P.2d 1085 (1949) (4-3 decision), criticized in Note, 23 So . Calif. L. REv. 109 (1949). 